\title{
Analyses of Ashes from the Tidd PFBC Advanced Particulate Filter.
}

\section{Topical Report}

T.R. Snyder

D.H. Pontius

August 1995

Work Performed Under Contract No.: DE-AC21-94MC31160

For

U.S. Department of Energy

Office of Fossil Energy

Morgantown Energy Technology Center

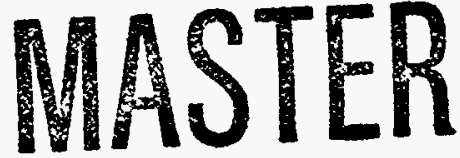

Morgantown, West Virginia

By

Southern Research Institute

Birmingham, Alabama 


\section{DISCLAIMER}

This report was prepared as an account of work sponsored by an agency of the United States Government. Neither the United States Government nor any agency thereof, nor any of their employees, makes any warranty, express or implied, or assumes any legal liability or responsibility for the accuracy, completeness, or usefulness of any information, apparatus, product, or process disclosed, or represents that its use would not infringe privately owned rights. Reference herein to any specific commercial product, process, or service by trade name, trademark, manufacturer, or otherwise does not necessarily constitute or imply its endorsement, recommendation, or favoring by the United States Government or any agency thereof. The views and opinions of authors expressed herein do not necessarily state or reflect those of the United States Government or any agency thereof.

This report has been reproduced directly from the best available copy.

Available to DOE and DOE contractors from the Office of Scientific and Technical Information, 175 Oak Ridge Turnpike, Oak Ridge, TN 37831; prices available at (615) 576-8401.

Available to the public from the National Technical Information Service, U.S. Department of Commerce, 5285 Port Royal Road, Springfield, VA 22161; phone orders accepted at (703) 487-4650. 


\title{
Analyses of Ashes from the Tidd PFBC Advanced Particulate Filter
}

\section{Topical Report}

T.R. Snyder

D.H. Pontius

Work Performed Under Contract No.: DE-AC21-94MC31160

\author{
For \\ U.S. Department of Energy \\ Office of Fossil Energy \\ Morgantown Energy Technology Center \\ P.O. Box 880 \\ Morgantown, West Virginia 26507-0880
}

By

Southern Research Institute

2000 Ninth Avenue South

P.O. Box 55305

Birmingham, Alabama 35255-5305 


\section{EXECUTIVE SUMMARY}

Early observations of the Advanced Particulate Filter (APF) at the Tidd PFBC Demonstration Plant led to the conclusion that tenacious ash deposits formed in the filter vessel and induced stresses that resulted in bent or broken ceramic candle filter elements. The proximity of these bent and broken candle filter elements to large, strong ash deposits emphasized the need to prevent or control the growth of these deposits, facilitate their on-line removal, and/or to develop filter design criteria to minimize their effects on individual filter elements.

The chemical characteristics of the ashes collected in the Tidd APF combined with the environment within the filter vessel tend to cause ash deposits formed in the filter vessel to consolidate and strengthen. Much of the research described in this report addresses the formation of these deposits. One theory that may explain the growth and strengthening of these deposits is based on the formation of eutectics such as various calcium aluminosilicate compounds. These eutectics form when primary coal ash particles (containing a large percentage of aluminosilicate compounds) come into physical contact with sorbent-derived ash particles which contain relatively large amounts of magnesium and/or calcium.

Aluminosilicate compounds in the coal ash particles react with alkali metals in the sorbent ash particles to form eutectics that melt at relatively low temperatures. This reduction in melting points combined with long-term exposure to the temperatures in the filter vessel tends to create relatively soft, sticky layers on the surfaces of the ash particles. The surface tension of the near-liquid layer on the particles pulls adjacent ash particles closer together, thereby eventually consolidating the structure of the entire ash agglomerate. This mechanism may have been further enhanced by the relatively small size of the ash particles in the agglomerate.

The optimum solution to the problems caused by the ash aggregates that have been consolidated and strengthened by pervasive eutectic formation is the removal of these aggregates from the APF before the eutectics have had enough time to develop. The approach that proved most successful in eliminating the deposits was the total bypassing of the cyclone upstream of the APF. This increased the size distribution of the particles forming the various ash deposits, thereby decreasing their inherent cohesivity. These agglomerates of lower cohesivity did not have sufficient strength to remain in the APF long enough to undergo consolidation. The effects of gravity or vibration caused them to fall off the surface on which they initially formed. 


\section{TABLE OF CONTENTS}

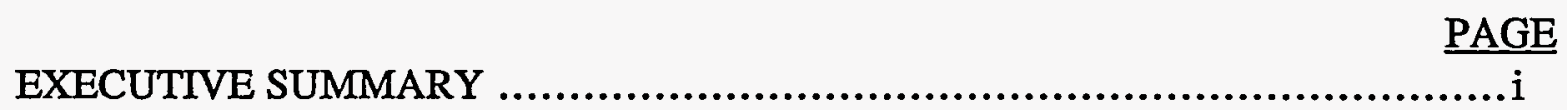

TABLE OF CONTENTS ........................................................... ii

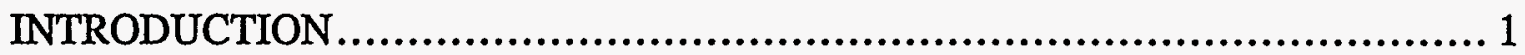

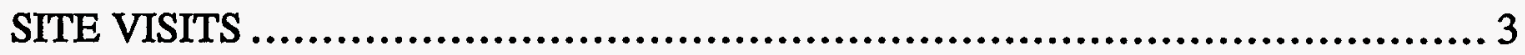

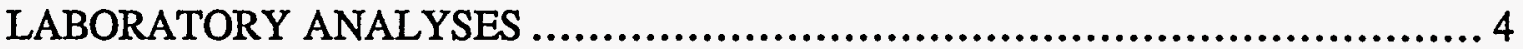

MECHANISMS CONTROLLING THE CONSOLIDATION OF ASH DEPOSITS .. 12

CONCLUSIONS......................................................................... 15

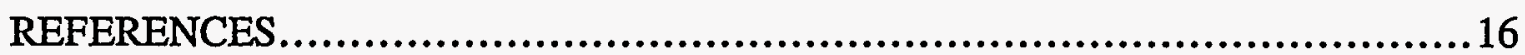




\section{INTRODUCTION}

This topical report summarizes Southern Research Institute's assessments of the effects that ash characteristics had on the performance of the Advanced Particulate Filter located at the Tidd PFBC facility operated by the American Electric Power Service Corporation. These analyses were commissioned and funded by the Department of Energy's Morgantown Energy Technology Center as a part of their Hot Gas Cleanup (HGCU) Program. Tests of the APF at Tidd were conducted between October, 1992 and the spring of 1995 to evaluate the ability of this filter system to efficiently and reliably remove entrained $\mathrm{PFBC}$ particles from flue gas at temperatures between 1200 and $1600{ }^{\circ} \mathrm{F}$ and at pressures around 10 atmospheres.

The Tidd APF was designed by the Westinghouse Science and Technology Center to perform as a barrier filter. It was designed to use periodic reverse pulses of high pressure air to remove ash from the filtering surface of the ceramic candle filter elements. A schematic diagram of the Tidd APF is shown in Figure 1. During its operation, the APF handled 1/7th of the process stream from the 70 MWe Tidd PFBC Demonstration Plant. In its initial configuration, the APF was preceded by a cyclone designed to capture most of the entrained particulate matter. The environment within the APF and specific characteristics of the PFBC ash presented unique challenges for this installation. As operating experience with the APF accumulated, the cyclone upstream of the APF was first derated, and then completely bypassed to increase the mean size of the ash particles entering the filter vessel.

The operating history of the Tidd APF demonstrated the importance of ash characteristics in determining the overall performance of the filter. Although performance of different types of candle filter elements that were tested varied considerably, ash deposits that formed in the APF were the primary factor that determined the integrity of the barrier filter. Almost all ash samples removed from the filter vessel comprised relatively fine particles, and were highly cohesive. Observations of the performance of the APF were made throughout its operating history, coupled with laboratory analyses of bulk ash and ash deposits collected in the filter assembly. These analyses indicated that after ash particles were initially deposited, the ash deposits gradually underwent a physical restructuring or consolidation that significantly reduced their overall porosity and increased their strength. The high temperatures in the filter vessel combined with the chemistry and morphology of the PFBC ash to form strong, tenacious ash deposits at various locations in the filter vessel. The presence of these deposits subsequently led directly to bent and broken candle filter elements. Similar, although less severe, problems have been observed at the Karhula PFBC facility located in Finland. 


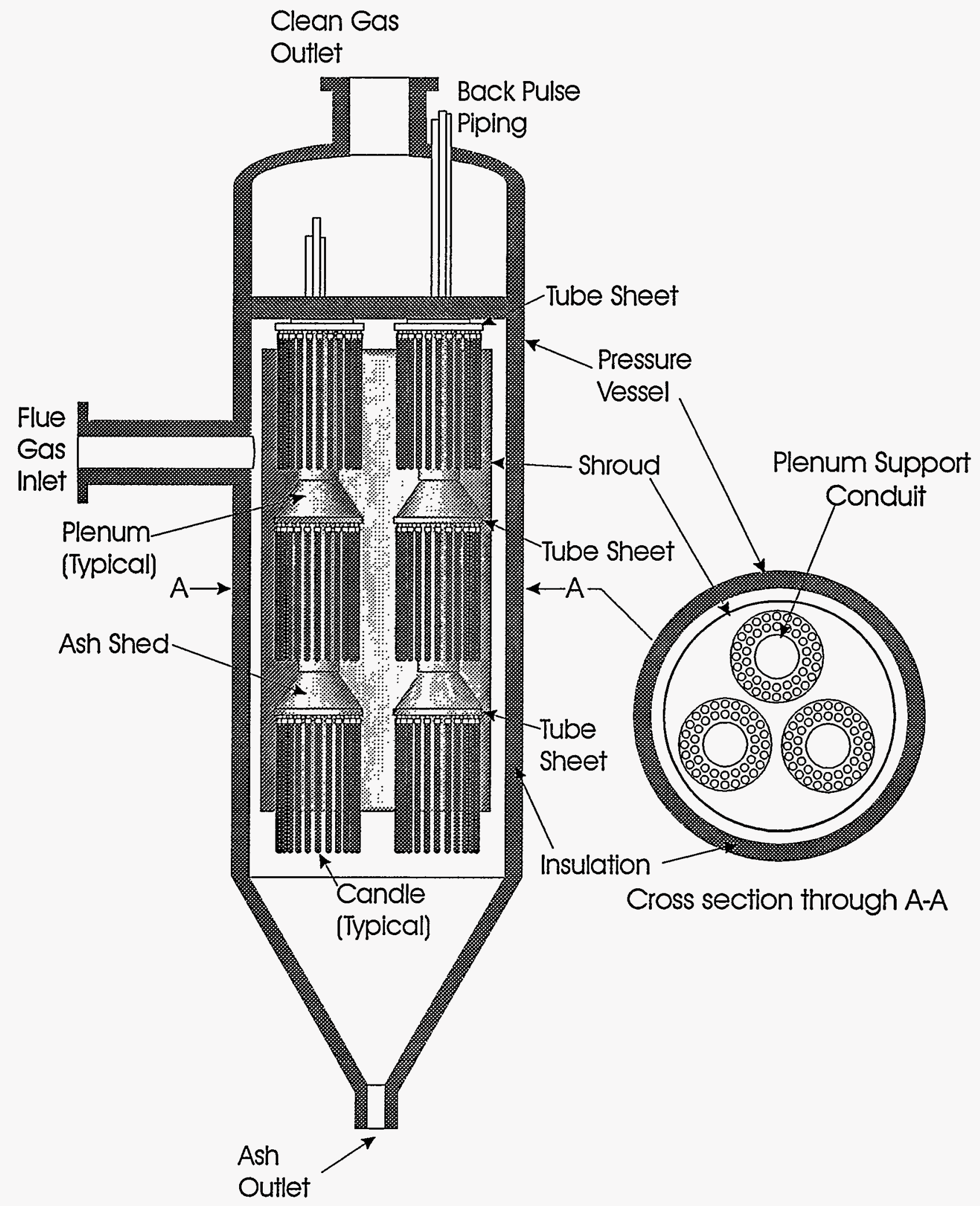

Figure 1. General features of the APF at the Tidd Demonstration Plant 


\section{SITE VISITS}

Southern Research Institute personnel made four site visits to the Tidd APF to inspect and document the condition of the filter vessel and to collect representative samples of the various deposits of ash found in the APF for analysis. When the filter assembly was opened during the first of these site visits on September 30,1993, extensive deposits of ash were found on candle surfaces, bridged between candles, and on nonfiltering surfaces (ash sheds, plenum support conduits, and on the underside of the tube sheet). Deposits found on these non-filtering surfaces were formed by the gradual deposition of particles as a result of turbulent diffusion. Some of these passive deposits were up to six inches thick, with high tensile strength. Many of the candle filter elements were covered by filter cakes up to one inch thick. Like the passively deposited agglomerates of ash, these filter cakes also had high tensile strength.

The filter vessel was again opened for inspection and refitting on May 5, 1994. Despite the relative cleanliness of the candles, significant deposits of ash were observed at several other locations in the assembly. The undersides of each of the nine tube sheets were coated with deposits of ash about eight inches thick. Although the outer (presumably the most recently deposited) portions of these deposits were fairly fluffy, the inner regions were hard, strong, and well consolidated. Similar deposits were apparent on the ash sheds above the middle and bottom plenums. These deposits were about three inches thick, and were also strong and well consolidated. Strong, thick deposits were present on the plenum support conduits that are positioned in the center of the top and middle plenum assemblies. These deposits were thick enough (over four inches) in most areas to envelop the inner ring of candles in these plenum assemblies. Many of the innermost candles in the top and middle plenums were bent away from the plenum support conduits. The regions between these candles and the plenum support conduits were almost completely filled with ash.

Observations of the APF during the May 1994 refitting indicated that severe bridging of ash between adjacent candles was still a serious problem. Many ash bridges were present, some of which extended from the deposit on the underside of the tube sheet all the way down to the conical surface of the ash shed below the bottom ends of the candles. Ash bridges were identified in many different stages of formation. Most ash bridges were found in the top and middle plenums, which were also the locations where most of the severely bent candles were found. The bottom plenums had the fewest ash bridges, and the fewest bent or broken candles. As was observed previously, the ash deposits throughout the APF had high tensile strength. However, the filter cakes observed during this second site visit were only about 0.4 inch thick, compared with the one inch thick cakes present in September 1993. 
From May 1994 until the shutdown of the facility in the spring of 1995, operation of the APF focused on two separate approaches to eliminating the ash bridges previously formed between candle filter elements and nearby surfaces. The first approach involved increasing the mean size of the entrained particles entering the filter vessel by derating, and later bypassing, the cyclone located just upstream of the filter. The other approach was to remove the inner ring of candle filter elements from the top and middle plenum assemblies. Although this latter approach involved removing $25 \%$ of the ceramic candle filter elements, and consequently $25 \%$ of the active surface area, it was implemented to increase the separation between the candle filter elements and the ash sheds and plenum support conduits, reducing the likelihood that ash bridges would form at these locations.

When the APF was opened on October 27, 1994 a significant number of candle filter elements were broken, and ash deposits were present at various locations throughout the filter assembly. As observed in two previous site visits, the region under each tube sheet where the candle filter elements were mounted was completely packed with ash deposits. Although the number of ash bridges adjacent to the filter elements was reduced compared to the two prior observations, there were still a few large ash bridges formed between the lower portion of filter elements in the top and middle plenum assemblies and the ash sheds and/or the plenum support conduits. In general, the filtering surfaces of the intact filter elements were relatively clean, except for regions of the candles just below the tube sheet deposits mentioned above. The surfaces of the plenum support conduits and the ash sheds were cleaner than previously observed; however, several thick ash deposits were present on portions of these surfaces. Bridging of ash between filter elements in the bottom plenums did not seem to be a serious problem.

The APF was opened once more on May 11, 1995 after the final shutdown of the Tidd Demonstration Plant. During this last operating period, the cyclone upstream of the APF was entirely bypassed to get as many relatively large particles into the filter vessel as possible. In general, the filter assembly was quite clean. The only significant deposits of ash were on the underside of the tube sheets, much like the deposits found in these locations during prior inspections. Most of the broken candle filter elements were of a particular experimental design. Most of the other filter elements were intact.

\section{LABORATORY ANALYSES}

During each of the four site visits described above, Southern Research Institute personnel collected a suite of ash samples from various locations in the APF for analysis. These samples included large pieces of the various types of deposits present throughout the filter vessel, as well as samples of loose ash that were found at several places in the APF. Analyses performed on ash deposits included SEM examinations of 


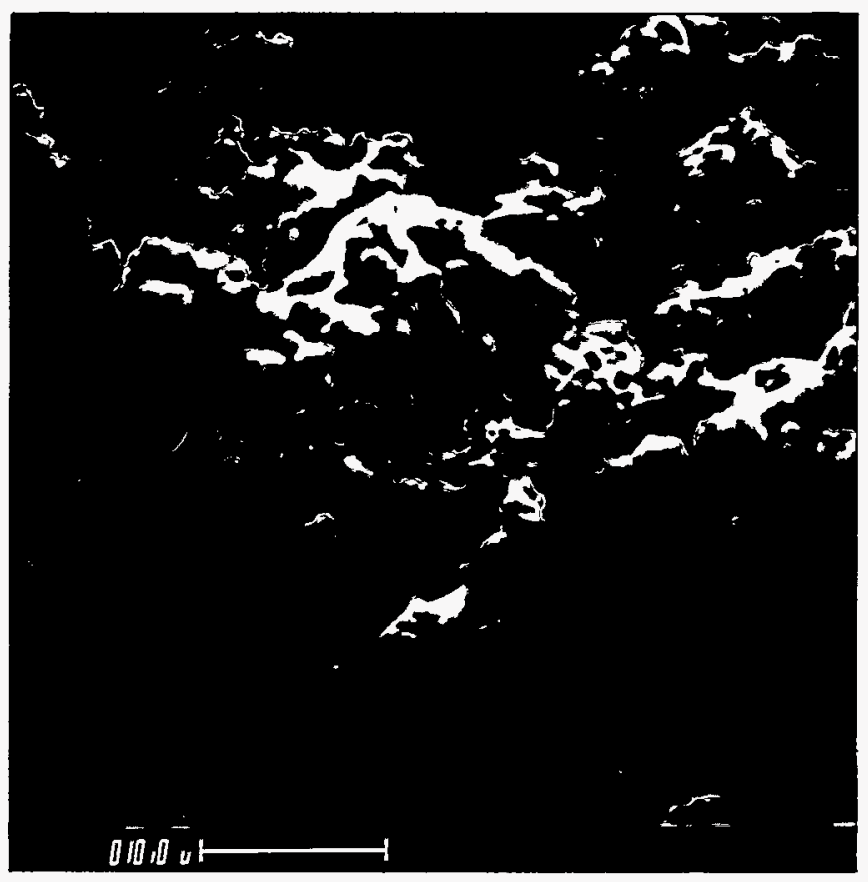

Figure 2. SEM photograph of a fresh fracture surface of an ash agglomerate taken from an ash shed in the Tidd APF in October 1994. 
initially collected. We believe this amorphous mass was the result of eutectic formation as discussed later in this report. Passively deposited agglomerates of ash like the one shown in Figure 2 were found to have porosities around $74 \%$.

An SEM microprobe was used to examine agglomerates of ash obtained from the filter vessel in May 1994. The device performs elemental analyses on selected $1 \mu \mathrm{m}$ diameter hemispherical regions. There was little consistency from region to region in the various specimens that were examined. Each particle observed was apparently a special case. Some particles were almost completely iron, others were very high in calcium or magnesium. Aluminosilicate particles were also common. The shapes and sizes of the particles also varied considerably. Some particles showed evidence of having been melted and resolidified. Such particles, to the extent that it was possible to determine, were enriched in magnesium because of the formation of $\mathrm{MgSO}_{4}$. The bonds between particles showed some enhanced levels of $\mathrm{Mg}$, accompanied by such other species as $\mathrm{Ti}, \mathrm{Al}, \mathrm{Ca}$, and $\mathrm{S}$. Although conclusions are hard to verify because of the limitations of the technique and the heterogeneity of the samples, particles rich in $\mathrm{Mg}$ and S apparently softened during combustion and/or collection and residence in the filter vessel. The presence of significant amounts of $\mathrm{Mg}$ and $\mathrm{S}$ in the ash particles may have enhanced the chances for eutectic formation between particles.

When we slowly covered Tidd ash nodules with water, they rapidly disintegrated. When we performed this same procedure with ethanol, the nodules maintained their shape, and when they dried, they seemed to recover all of their initial strength. Apparently the hydration of various compound(s) in the ash or the dissolution of soluble compounds into the water broke apart the interparticle bonds in the nodules.

The most useful information describing the bulk ash samples was derived from determinations of size distribution, chemical analyses, and uncompacted bulk porosity measurements. The most enlightening descriptions of size distributions were obtained with a combination of sieving and sedigraphic analyses. Prior to derating and eventually bypassing the cyclone upstream of the APF, the ash particles collected at various places in the filter vessel were very fine, with MMD's around 3 to $5 \mu \mathrm{m}$. As efforts progressed to increase the size of the ash entering the APF by derating the cyclone, somewhat larger MMD's were observed. However, the major changes in the size distributions of the ashes collected in the APF did not occur until the last period of operation, during which the cyclone was completely bypassed.

We performed sieve analyses on ashes collected in October 1994, after derated cyclone operation, and in May 1995, after operation with the cyclone completely bypassed. The data in Table 1 show that bypassing the cyclone between October 1994 and May 1995 significantly increased the size distributions of ash collected in the APF. The sieving process used on these five ashes separated a portion of the original ashes into 
three size fractions: particle diameters greater than $45 \mu \mathrm{m}$, particle diameters between $15 \mu \mathrm{m}$ and $45 \mu \mathrm{m}$, and ash particles with diameters less than $15 \mu \mathrm{m}$. (The sieving process caused this last, smallest fraction to be discarded along with the isopropanol used to wash the particles through the sieves with $45 \mu \mathrm{m}$ and $15 \mu \mathrm{m}$ openings.)

Table 1

Sieve Analyses of Tidd Ashes, \% wt.

\begin{tabular}{|l|c|c|c|}
\hline \multicolumn{1}{|c|}{ location, date } & diam $>45 \mu \mathrm{m}$ & $45 \mu \mathrm{m}>$ diam $>15 \mu \mathrm{m}$ & diam $<15 \mu \mathrm{m}$ \\
\hline \hline Tube sheet, Oct. 1994 & 4.03 & 17.3 & 78.6 \\
\hline Ash shed, Oct. 1994 & 0.64 & 3.84 & 95.5 \\
\hline Tube sheet, May 1995 & 28.9 & 50.7 & 20.4 \\
\hline Filter cake, May 1995 & 30.1 & 34.3 & 35.6 \\
\hline Tube sheet, May 1995 & 44.8 & 33.3 & 21.9 \\
\hline
\end{tabular}

In Figure 3, the size distribution data for these five samples obtained with the sieves have been combined with size distribution data obtained with a sedigraph. These data clearly show the increase in particle size induced by bypassing the cyclone.

The ash corresponding to the last row in Table 1 (tube sheet, May 1995) behaved much more like a free flowing powder than the other samples collected on the same site visit. This free flowing ash exhibited the largest particle size distribution of those ashes that were analyzed. When this ash was removed from the tube sheet, it was loose and fluffy, unlike the other ash samples that were consolidated into nodules and deposits. This type of difference is common with fine powders. Powders normally become more free flowing as their particle size distribution becomes coarser.

Chemical analyses of this free flowing ash and one of the nodular ashes were performed to determine if differences other than particle size might account for the tendency of the coarser ash to behave like a free flowing powder. Chemical analyses of these two ashes and the size-separated portions generated from them during sieving are summarized in Table 2. 


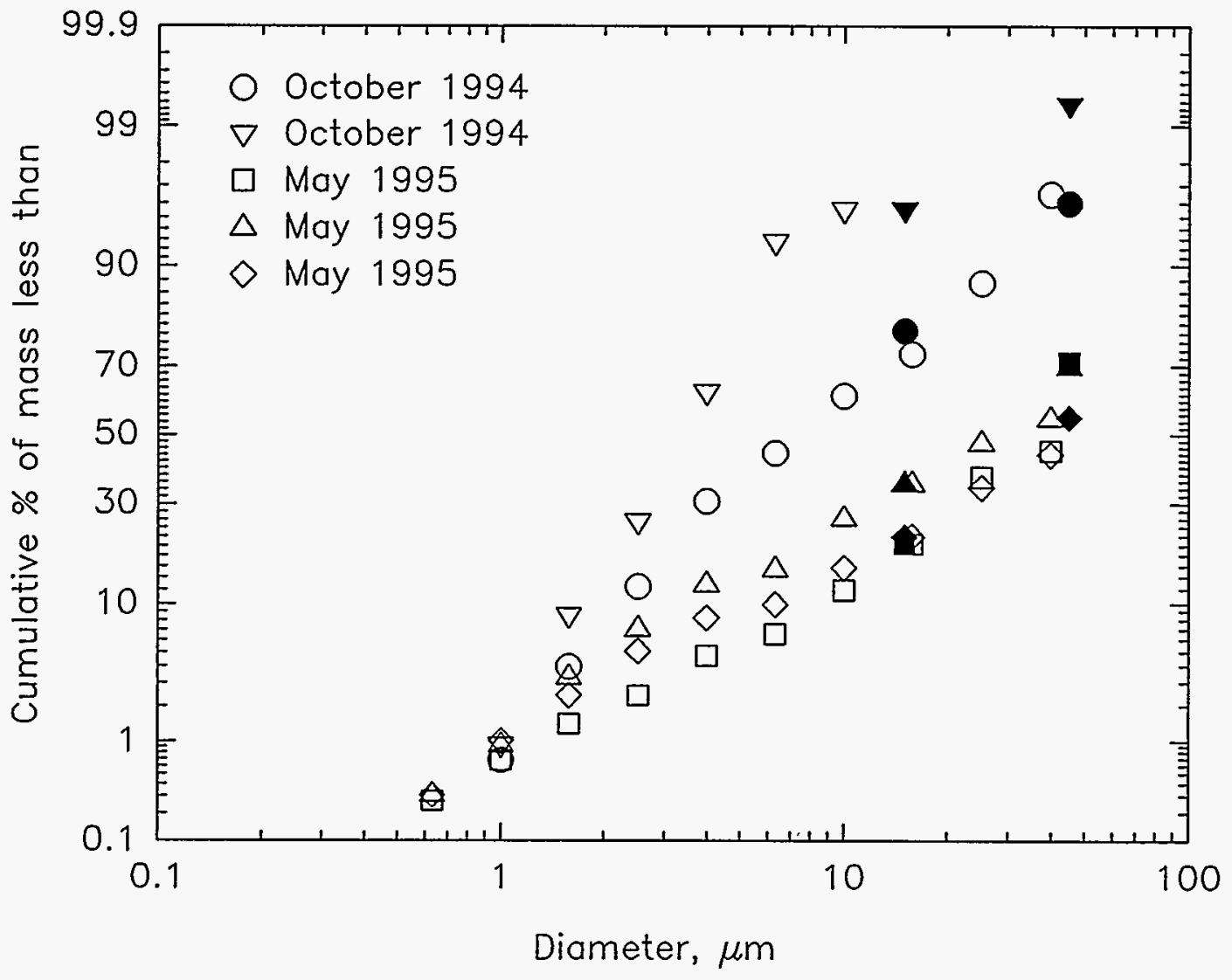

Figure 3. Cumulative size distribution data measured with a sedigraph and sieves for five ashes collected from the Tidd APF. The hollow data points represent sedigraphically obtained Stokes' diameters. The filled data points represent data obtained in the sieve analyses. 
Table 2

Chemical Analyses of Tidd Ashes Collected in May, 1995, \% wt.

\begin{tabular}{|l|c|c|c|c|c|c|}
\hline & \multicolumn{3}{|c|}{ fine, nodular ash (filter cake) } & \multicolumn{2}{c|}{ coarse, free flowing ash (tube sheet) } \\
\cline { 2 - 7 } constituent & all diameters & $\mathrm{d}>45 \mu \mathrm{m}$ & $\begin{array}{l}15 \mu \mathrm{m}<\mathrm{d}, \\
\mathrm{d}<45 \mu \mathrm{m}\end{array}$ & all diameters & $\mathrm{d}>45 \mu \mathrm{m}$ & $\begin{array}{c}15 \mu \mathrm{m}<\mathrm{d}, \\
\mathrm{d}<45 \mu \mathrm{m}\end{array}$ \\
\hline $\mathrm{Li}_{2} \mathrm{O}$ & 0.01 & 0.01 & 0.01 & 0.01 & 0.01 & 0.01 \\
\hline $\mathrm{Na}_{2} \mathrm{O}$ & 0.29 & 0.16 & 0.23 & 0.27 & 0.13 & 0.20 \\
\hline $\mathrm{K}_{2} \mathrm{O}$ & 1.3 & 0.83 & 1.3 & 1.2 & 0.77 & 1.1 \\
\hline $\mathrm{MgO}$ & 8.3 & 11.3 & 8.5 & 13.2 & 16.5 & 13.5 \\
\hline $\mathrm{CaO}$ & 14.1 & 18.1 & 15.0 & 20.5 & 24.7 & 21.0 \\
\hline $\mathrm{Fe}_{2} \mathrm{O}_{3}$ & 7.1 & 4.8 & 7.5 & 8.0 & 6.2 & 9.9 \\
\hline $\mathrm{Al}_{2} \mathrm{O}_{3}$ & 11.7 & 7.5 & 10.8 & 10.8 & 7.2 & 9.5 \\
\hline $\mathrm{SiO}_{2}$ & 26.1 & 17.6 & 26.0 & 25.1 & 19.6 & 25.6 \\
\hline $\mathrm{TiO}_{2}$ & 1.2 & 0.41 & 0.46 & 1.1 & 0.33 & 0.49 \\
\hline $\mathrm{P}_{2} \mathrm{O}_{5}$ & 0.15 & 0.12 & 0.14 & 0.14 & 0.10 & 0.14 \\
\hline $\mathrm{SO}_{3}$ & 30.1 & 38.5 & 28.5 & 19.5 & 22.9 & 17.4 \\
\hline $\mathrm{LOI}$ & 13.5 & 19.6 & 15.3 & 1.5 & 2.4 & 1.1 \\
\hline soluble SO$_{4}=$ & 29.7 & 36.0 & 29.8 & 22.4 & 26.3 & 20.6 \\
\hline
\end{tabular}

Like other Tidd ashes we analyzed, the primary elemental constituents of these samples were calcium, magnesium, aluminum, silicon and sulfur. These analyses demonstrated that the larger ash particles in both samples contain more $\mathrm{Mg}, \mathrm{Ca}, \mathrm{SO}_{3}$, and have higher LOI values than the smaller particles. The smaller particles are richer in $\mathrm{Al}$, $\mathrm{Na}, \mathrm{K}, \mathrm{Fe}, \mathrm{Ti}$, and $\mathrm{Si}$. These results suggest that the larger ash particles are derived mainly from the sorbent used in the combustion process, while the smaller particles are derived mainly from the coal. This is supported by comparisons of the concentrations of calcium and magnesium in the two parent samples and their corresponding size fractions. The coarser tube sheet ash contains about $50 \%$ more calcium and magnesium than the finer filter cake ash. The particles too large to pass through the 45 $\mu \mathrm{m}$ sieve also had a different appearance than the finer particles. Whereas the finer particles all had the characteristic reddish-orange color associated with PFBC ashes, most of the larger particles were brown. A few of them were black or white. All of these differences suggest that the sorbent-derived ash particles were somewhat larger than the coal-derived ash particles in these samples.

Another interesting difference in these two samples is evident in the acid/base ratios as defined in Table 3. We believe that the differences in these ratios are due to the exposure of the filter cake ash to much more flue gas than the ash obtained from the passive deposit under the tube sheet. As flue gas was filtered through the filter cake, additional $\mathrm{SO}_{2}$ in the flue gas was captured by calcium and/or magnesium still remaining in the ash. Although unreacted sorbent present in the passive ash deposits 
could still react with $\mathrm{SO}_{2}$ in the flue gas, the reaction was diminished because the flue gas in direct contact with the ash particles in the deposit was exchanged or refreshed relatively slowly. We attribute the higher LOI of the filter cake ash to the presence of the increased amounts of sulfur captured by chemical adsorption in the filter cake. The comparisons discussed above suggest that it is possible that the increased flowability of ash from under the tube sheet may be partially due to chemical differences as well as differences in size distribution.

Table 3

Acid/Base Ratios in Tidd Ashes Collected in May, 1995

\begin{tabular}{|c|c|c|}
\hline location & $\mathrm{SO}_{3} /(\mathrm{Ca}+\mathrm{Mg})$ & soluble $\mathrm{SO}_{4}{ }^{{ }} /(\mathrm{Ca}+\mathrm{Mg})$ \\
\hline filter cake & 1.3 & 1.3 \\
\hline tube sheet & 0.58 & 0.66 \\
\hline
\end{tabular}

In order to assess the effects that long residence time in the APF might have on ash chemistry, we performed mineral analyses of ashes from the APF hopper and filter cakes formed on the candle filter surfaces. These analyses are summarized in Table 4. Most of the calcium and magnesium in these ash samples was derived from use of limestone and/or dolomite in the fluidized bed. The other major constituents of the ash were derived from the coal. (These chemical comparisons of hopper ashes and filter cake ashes have also helped to identify the mechanisms controlling the consolidation of ash deposits in the APF. These discussions are presented later in this report.)

Table 4

Chemical Analyses of Tidd Ashes Collected in 1993, \% wt.

\begin{tabular}{|l|c|c|c|c|}
\hline constituent & \multicolumn{2}{|c|}{ hopper ashes } & \multicolumn{2}{c|}{ filter cake ashes } \\
\hline \hline $\mathrm{Na}_{2} \mathrm{O}$ & 0.30 & 0.31 & 0.30 & 0.27 \\
\hline $\mathrm{K}_{2} \mathrm{O}$ & 1.6 & 1.42 & 1.73 & 1.77 \\
\hline $\mathrm{MgO}$ & 9.9 & 9.63 & 8.77 & 7.96 \\
\hline $\mathrm{CaO}$ & 15.3 & 15.48 & 14.16 & 13.67 \\
\hline $\mathrm{Fe}_{2} \mathrm{O}_{3}$ & 5.3 & 6.49 & 4.79 & 5.63 \\
\hline $\mathrm{Al}_{2} \mathrm{O}_{3}$ & 13.4 & 11.80 & 13.01 & 13.63 \\
\hline $\mathrm{SiO}_{2}$ & 19.2 & 21.29 & 23.03 & 22.89 \\
\hline $\mathrm{TiO}_{2}$ & 0.50 & 0.56 & 0.61 & 0.07 \\
\hline $\mathrm{P}_{2} \mathrm{O}_{5}$ & 0.08 & 0.12 & 0.11 & 0.10 \\
\hline $\mathrm{SO}_{3}$ & 33.6 & 31.10 & 31.06 & 31.38 \\
\hline $\mathrm{LOI}^{\text {soluble } \mathrm{SO}_{4}}{ }^{2}$ & 1.5 & 2.96 & 1.45 & 1.84 \\
\hline
\end{tabular}


In other chemical analyses, we leached a sample of Tidd ash with water. These analyses indicated that large proportions, but not all, of the $\mathrm{Mg}, \mathrm{Ca}, \mathrm{K}, \mathrm{Na}$, and $\mathrm{SO}_{4}$ were leached out of the ash in this procedure. Analyses of the leachate showed that the leachable sulfate ions were almost totally bound up as magnesium sulfate and calcium sulfate. At least $30 \%$ by weight of the ash was soluble in water.

\section{MECHANISMS CONTROLLING THE CONSOLIDATION OF ASH DEPOSITS}

Our observations of the strengths and porosities of the various deposits formed in the Tidd APF indicate that initially these deposits form loose, fluffy agglomerates with porosities around 85 to $90 \%$, depending on the size distribution of the ash particles deposited. After some period of exposure to the conditions in the APF, the deposits become much stronger, and often have porosities as low as 69 to $74 \%$. This behavior has been observed for filter cakes and passively deposited ash agglomerates. The specific mechanisms involved in this type of transformation, referred to in this report as consolidation, have not been positively verified. However, different theories have been proposed, and a significant amount of circumstantial evidence exists that can be used to examine their validity.

Two basic mechanisms are available which may account for the consolidation of ash deposits. The first of these involves the adsorption of compound(s) out of the flue gas onto the surfaces of the previously collected ash particles. If this adsorbed material occupies enough of the interparticle voids, its presence could account for the decreased porosity of the ash deposit. The compound in the flue gas most likely to be available for this type of mechanism is $\mathrm{SO}_{2}$. Because the PFBC process captures only about 90 $\%$ of the sulfur in the coal, a significant concentration of $\mathrm{SO}_{2}$ is present in the flue gas entering the APF. The ash that collects in the APF contains significant amounts of unspent calcium and magnesium with which the $\mathrm{SO}_{2}$ can react. Calcium sulfate and magnesium sulfate are the compounds most likely to be formed as a result of the chemical adsorption of $\mathrm{SO}_{2}$ by ash particles.

To determine whether this type of adsorption is responsible for the observed consolidation of ash deposits in the Tidd APF, it is important to determine how much calcium and/or magnesium sulfate would have to form to fill the interparticle voids in the ash deposits to the degree observed in the APF. The deposits are initially formed with porosities around 85 to $90 \%$ (15 to $10 \%$ solid material). Subsequently they gradually transform into deposits with porosities around 69 to $74 \%$ (31 to $26 \%$ solid material). This means that as the aggregates age in the APF, either the volume of solid material has been approximately doubled from some source other than the primary particles (condensation or adsorption from the flue gas), or that the primary particles have rearranged themselves to occupy about half of their original total volume. 
We then compared the chemistry of two ash samples that had been obtained from a well-consolidated one inch-thick filter cake that had resided in the APF for an extended period with APF hopper ashes from the same period of operation. (Hopper ash provides the best candidate for ash that has had minimal exposure to the conditions in the APF.) The chemistries we measured for these two types of samples are presented in Table 4. Since the sulfur contents of these two types of ashes (expressed by measured $\mathrm{SO}_{3}$ and soluble sulfate levels) are not significantly different, it is unlikely that enough $\mathrm{SO}_{2}$ becomes captured by the unspent sorbent in the ash after an ash deposit is initially formed.

Another way to compare the chemistries of these two types of samples is to examine the relative concentrations of non-volatile components. If the flue gas contributed large amounts of mass to the aggregate through condensation or adsorption, the chemical constituents of this added mass would be limited to compounds that could exist as a vapor at the normal operating conditions of the APF. Although many compounds could satisfy these requirements, some of the major constituents found in the fly ash do not. Three major constituents that will not be found in a gaseous state in the APF are iron, aluminum and silicon. When we compare the mineral analyses of Tidd APF hopper ashes with mineral analyses of aged Tidd filter cake ashes (see Table 4), the iron, aluminum, and silicon contents of the two types of samples are very similar. Since the concentrations of these three non-volatile elements are not significantly lower in filter cake ash than in hopper ash, it is apparent that essentially all of the mass of the filter cake is due to the original ash particles, and not to any significant deposition of gas-phase constituents from the flue gas. These results do not preclude formation of calcium and/or magnesium sulfate in the Tidd APF; however, the chemical analyses do not support the production of these compounds as the primary mechanism by which ash deposits consolidate.

Studies of the buildup of ash deposits on boiler tubes in conventional pulverized-coal fired boilers describe another mechanism which may account for the apparent consolidation of the Tidd ash deposits. Many of the ash particles collected in HGCU filter assemblies are derived directly from coal particles. These ash particles often contain a large percentage of aluminosilicate compounds. The other main source of ash particles is the sorbent used in the PFBC process. Sorbent-derived ash particles contain relatively large amounts of calcium and/or magnesium. Once these two types of ash particles come in contact with each other in the agglomerates formed in the filter vessel, the aluminosilicate compounds in the coal fly ash tend to react with alkali and alkaline metals in the sorbent ash particles to form eutectics that melt at relatively low temperatures ${ }^{1}$. The progress of these reactions is supported by the intimate contact of the ash particles in the agglomerate and by long-term exposure of the ash particles to the temperatures in the filter vessel. 
Most of the research into the formation of these eutectics has examined the formation of calcium aluminosilicate compounds (e.g. $2 \mathrm{Ca} \cdot \mathrm{Al}_{2} \mathrm{O}_{3} \cdot \mathrm{SiO}_{2}$ or $\mathrm{CaO} \cdot \mathrm{Al}_{2} \mathrm{O}_{3} \cdot 2 \mathrm{SiO}_{2}$ ). Although pure forms of these compounds do not melt at the temperatures encountered in HGCU filter vessels (pure $2 \mathrm{Ca} \cdot \mathrm{Al}_{2} \mathrm{O}_{3} \cdot \mathrm{SiO}_{2}$ and $\mathrm{CaO} \cdot \mathrm{Al}_{2} \mathrm{O}_{3} \cdot 2 \mathrm{SiO}_{2}$ melt at around $2800^{\circ} \mathrm{F}$ ), impurities would almost certainly be present in these compounds because of the heterogeneous nature of coal fly ash particles. These impurities act as fluxing agents, thereby lowering the melting points of the eutectic mixtures. Because calcium and magnesium are also very effective fluxing agents, their presence in the ash particles also contributes significantly to lowering the melting points of the eutectic mixtures. It is likely that this reduction in melting points combines with long-term exposure to the temperatures in the filter vessel to create relatively soft, sticky layers on the surfaces of the ash particles ${ }^{2,3}$. As the viscosity of the outer layer of the ash particles decreases, the bonds between the particles become stronger because of the formation of liquid bridges between particles. Also, the surface tension of the near-liquid layer on the particles tends to pull adjacent ash particles closer together, thereby eventually consolidating the structure of the entire ash agglomerate. This mechanism may be further enhanced by the relatively small size of the ash particles in the agglomerate.

The formation of calcium sulfate, magnesium sulfate and/or sodium sulfate on the surfaces of incompletely reacted sorbent particles in the agglomerate may contribute to eutectic formation. The melting points of these compounds in their pure state exceed the operating temperature of the APF. However, these compounds may become part of eutectic mixtures like the ones discussed above. In this way, adsorption of $\mathrm{SO}_{2}$ from the flue gas and its subsequent chemical reactions with alkali components of the ash may play an important role in the consolidation of ash deposits.

The data show that the degree of consolidation of these agglomerates can not be accounted for by condensation and/or adsorption of materials from the flue gas. We believe the mechanism responsible for the extreme consolidation of these agglomerates of ash is a physical rearrangement of the ash particles due to the surface tension of melted or partially melted alkali-aluminosilicate eutectic mixture(s) that form at the contact points between adjacent particles after long-term exposure to the temperatures in the APF. Therefore the amorphous mass in which the particles are embedded (as seen in Figure 2) is derived directly from the primary coal ash particles and sorbent particles originally deposited on the surface of the aggregate. 


\section{CONCLUSIONS}

Operation of the Tidd APF has demonstrated the importance of ash characteristics in determining overall filter performance. Ash deposits that formed in the APF were the primary factor that determined the integrity of the barrier filter. The high temperatures in the filter vessel combined with the chemistry and morphology of the ash to form strong, tenacious deposits that often led directly to bent and broken candle filter elements. The ash deposits found in the Tidd APF initially formed as loose, fluffy agglomerates with porosities around 85 to $90 \%$, depending on the size distribution of the ash particles deposited. After some period of exposure to the conditions in the $\mathrm{APF}$, the deposits consolidated, resulting in stronger deposits with porosities as low as 69 to $74 \%$. This type of consolidation was observed for filter cakes and passively deposited ash agglomerates.

The ash particles collected in the APF were derived either from coal or sorbent particles. The coal-derived ash particles contained a large percentage of aluminosilicate compounds. The sorbent-derived ash particles contained relatively large amounts of calcium and/or magnesium. Once these two types of ash particles came in contact with each other in the agglomerates formed in the APF, the aluminosilicate compounds in the coal fly ash reacted with alkaline metals in the sorbent ash particles to form eutectics that melt at relatively low temperatures. The progress of these reactions was supported by the intimate contact of the ash particles in the agglomerate and by longterm exposure of the ash particles to the temperatures in the filter vessel. Because of the heterogeneous composition of coal fly ash, the eutectics that formed contained significant impurities which lowered their melting points even further. In addition, the calcium and magnesium in the sorbent-derived ash particles acted as fluxing agents, which also promoted the formation of these eutectic compounds.

It is likely that this reduction in melting points combined with long-term exposure to the temperatures in the filter vessel to create relatively soft, sticky layers on the surfaces of the ash particles. The surface tension of the near-liquid layer on the particles tended to pull adjacent ash particles closer together, thereby eventually consolidating the structure of the entire ash agglomerate. This mechanism may have been further enhanced by the relatively small size of the ash particles in the agglomerate.

Because of the mechanisms governing the consolidation of the ash deposits, it is doubtful that process changes such as slightly lowering the temperature in the APF, sorbent switching, or addition of a conditioning agent can be effective in inhibiting the formation of these eutectics and the subsequent consolidation and strengthening of the ash aggregates. The minimum operating temperature of the APF is strictly limited by the economics of the PFBC process. Past operation at reduced temperatures around 
$1250^{\circ} \mathrm{F}$ have not been able to prevent the formation of consolidated ash aggregates. Since magnesium and calcium are both excellent fluxing agents, altering the type of sorbent used in the PFBC process is not likely to alter the tendency for eutectic formation. Finally, the addition of any conditioning agent to the eutectic system is likely only to lower its melting point even further.

The optimum solution to the problems caused by the ash aggregates that have been consolidated and strengthened by pervasive eutectic formation is the removal of these aggregates from the APF before the eutectics have had enough time to develop. A large measure of success has been achieved by bypassing the cyclone upstream of the APF. This increases the size distribution of the particles forming the various ash deposits (filter cakes and passive deposits), thereby decreasing their inherent cohesivity. These agglomerates of lower cohesivity do not have sufficient strength to remain in the APF long enough to undergo consolidation. The effects of gravity and vibration cause them to fall off the surface on which they initially formed.

\section{REFERENCES}

1. O' Gorman, J.V. and P.L. Walker, Jr. "Thermal behavior of mineral fractions separated from selected American coals," Fuel 52, 71 (1973).

2. Wibberley, L.J. and T.F. Wall. "Alkali-ash reactions and deposit formation in pulverized-coal-fired boilers: experimental aspects of sodium silicate formation and the formation of deposits," Fuel 61, 93 (1982).

3. Helble, J.J., S. Srinivasachar, and A.A. Boni. "Factors influencing the transformation of minerals during pulverized coal combustion," Prog. Energy Combust. Sci. 16, 267 (1990). 
cover stock is $30 \%$ post-consumer waste and $30 \%$ pre-consumer waste, and is recyclable. 